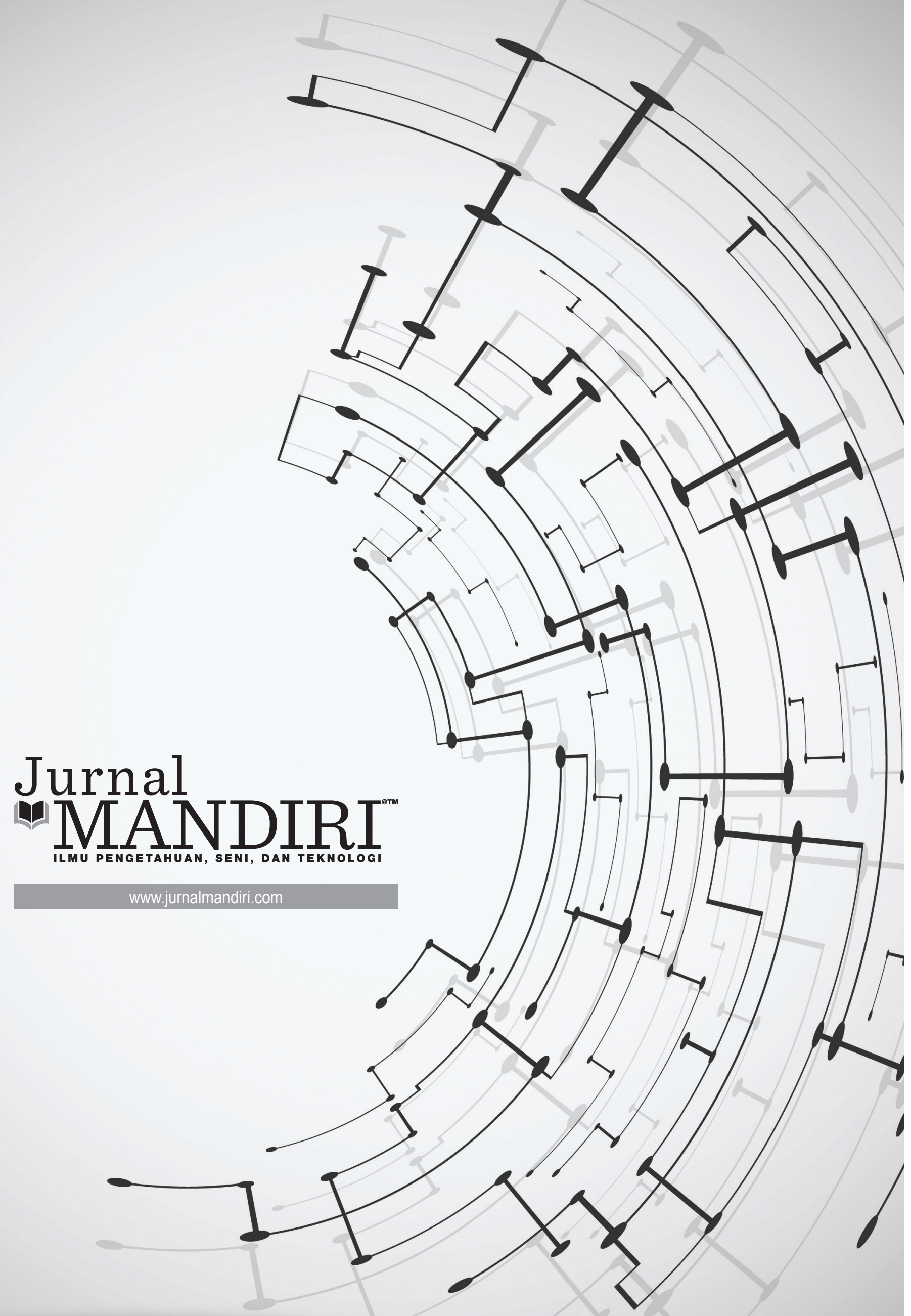


ISSN : 2580-3220, E-ISSN : 2580-4588

J. Mandiri., Vol. 1, No. 2, Desember 2017 (172 - 186)

(C2017 Lembaga Kajian Demokrasi

dan Pemberdayaan Masyarakat (LKD-PM)

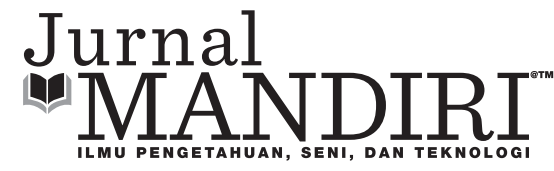

\title{
PENGARUH INSENTIF TERHADAP KINERJA GURU PADA SMK MULIA BUANA BOGOR
}

\author{
Aden Prawiro Sudarso \\ Dosen Program Studi Manajemen Fakultas Ekonomi \\ Universitas Pamulang, Kota Tangerang Selatan \\ aden.prawiro@gmail.com
}

\begin{abstract}
ABSTRAKSI
Tujuan dari penelitian ini adalah untuk mengetahui pelaksanaan pemberian insentif, mengetahui kinerja guru dan mengetahui seberapa besar pengaruh insentif terhadap kinerja Guru Pada SMK Mulia Buana Bogor. Berhubung populasi hanya 52 orang maka penulis menggunakan sampel jenuh dengan studi populasi. Jadi dalam penelitian ini penulis mengambil sampel sebanyak 52 orang. Tekhnik analisis data yang dipergunakan dalam penelitian ini adalah dengan analisis kuantitatif yaitu dengan mendeskripsikan keadaan responden serta deskripsi variabel penelitian dalam frekuensi dan prosentase dari hasil penyebaran kuisioner tersebut dengan melalui prosedur analisis data. Pelaksanaan pemberian jenis jenis kompensasi termasuk insentif Untuk dapat mengetahui seberapa besar pengaruh insentif terhadap kinerja Guru Pada SMK Mulia Buana Bogor, penulis menganalisa dengan menggunakan metode analisis korelasi product moment hasilnya sebesar 0,54 , artinya menunjukan pengaruh yang cukup kuat Koefisien determinasi dan uji signifikansi yang signifikan. Pengujian koefisien determinasi Pengaruh insentif terhadap SMK Mulia Buana Bogor sebesar 29,2\%. Hal ini menunjukan bahwa terdapat pengaruh antara kebijakan insentif terhadap kinerja guru, sehingga 29,2\% dipengaruhi oleh pemberian insentif sedangkan 70,8\% dipengaruhi oleh variabel atau faktor lain.
\end{abstract}

Kata Kunci : Insentif, Kompensasi dan Kinerja Guru

\section{PENDAHULUAN}

\section{Latar Belakang Masalah}

Dalam suatu organisasi pemberian jenis jenis kompensasi dapat mendorong kegiatan organisasi yang diharapkan mampu optimal agar proses manajemen dalam organisasi dapat berjalan efektif. Diharapkan insentif mampu memberikan motivasi yang efektif terhadap karyawan, dengan adanya insentif yang baik, adil dan layak diharapkan para karyawan mampu bekerja sesuai dengan kompetensi secara optimal.
Yayasan Pendidikan Mulia Buana adalah Lembaga sosial yang bergerak dibidang pendidikan formal yakni Sekolah Menengah Atas (SMA) dan Sekolah Menengah Kejuruan (SMK). Saat ini lembaga beralamat di Jalan Pesantren no. 23 Desa Kabasiran Kecamatan Parungpanjang Kabupaten Bogor. Dalam mengembangkan organisasi dua lembaga sekolah tersebut bekerja dengan satu manajemen yayasan. Yayasan Pendidikan Mulia Buana mempunyai visi yang diembannya yaitu "Men- 
jadikan Yayasan Pendidikan Mulia Buana Sebagai Pondasi Lembaga pendidikan yang unggul, terdepan dan berprestasi”. Adapun SMK Mulia Buana Bogor memiliki 4 program studi yaitu Administrasi Perkantoran, Akuntansi, Tekhnik Elektro dan Tekhnik Komputer Jaringan, Pimpinan harus memberikan pelayanan yang baik terhadap stakeholder dan hal tersebut dapat di wujudkan apabila pimpinan mampu mendorong guru - guru memberikan pelayanan terbaiknya apabila kebutuhan kebutuhan nya terpenuhi.

SDM yang berkualitas sangat diperlukan oleh setiap organisasi-organisasi. Untuk dapat melaksanakan tugas dan fungsinya dengan sebaik mungkin maka dibutuhkan kinerja yang baik dari sehingga terciptanya hasil kerja yang baik juga bagi perusahaan. Dari kinerja yang baik, guru dapat meningkatkan pelayanan yang optimal. Dari kinerja yang optimal membuat guru mendapatkan insentif dari hasil penjualan tersebut. Sehingga dengan adanya pemberian insentif yang diberikan organisasi membuat kinerja yang dihasilkan pun sangat baik bagi organisasi. Mengingat pentingnya insentif guna mempengaruhi kinerja guru, penulis menjadi tertarik untuk mengadakan penelitian dengan judul "Pengaruh Insentif Terhadap Kinerja Guru Pada SMK Mulia Buana Bogor"

\section{PEMBATASAN MASALAH}

Adapun permasalahan penelitian ini dibatasi pada permasalahan mengenai:

1. Yang dimaksud dengan insentif dalam penelitian ini adalah insentif yang berlaku pada SMK Mulia Buana Bogor.

2. Yang dimaksud dengan Kinerja dalam penelitian ini adalah kinerja yang ada pada SMK Mulia Buana BogorBogor.

3. Objek penelitian dilaksanakan pada guru SMK Mulia Buana Bogor.

4. Periode pengambilan data berlangsung pada bulan Juli 2017 sampai dengan September 2017.

\section{PERUMUSAN MASALAH}

Secara operasional masalah pokok dalam penelitian ini dapat dirumuskan sebagai berikut:

1. Bagaimana insentif pada SMK Mulia Buana Bogor?

2. Bagaimana Kinerja guru pada SMK Mulia Buana Bogor?

3. Bagaimana pengaruh insentif terhadap Kinerja guru SMK Mulia Buana Bogor?

\section{TUJUAN PENELITIAN}

1. Untuk mengetahui pelaksanaan insentif pada SMK Mulia Buana Bogor.

2. Untuk mengetahui Kinerja guru pada SMK Mulia Buana Bogor.

3. Untuk mengetahui seberapa besar Pengaruh insentif terhadap kinerja guru SMK Mulia Buana Bogor.

\section{TINJAUAN TEORITIK}

\section{Insentif}

Menurut Veitzhal Rivai (2009), Mengemukakan bahwa insentif adalah bentuk pembayaran yang dikaikatkan dengan dengan kinerja dan grainsharing, sebagai pembgin keuntungan bagi karyawan akibat peningkatan produktivitas atau penghematan biaya. Menurut $\mathrm{H}$. Hadari Nawawi (2008), mengemukakan bahwa insentif adalah "Penghargaan atau ganjaran yang diberikan untuk memotivasi para karyawan agar produktivitasnya tinggi dan sifatnya tidak tetap". Menurut Hendri simamora (2007), mengatakan bahwa pengertian insentif adalah: "Kompensasi yang mengaitkan bayaran atas dasar untuk dapat meningkatkan produktivitas para karyawan guna mencapai keunggulan yang kompetitif". Tujuan utama Insentif menurut Veitzhal Riva'i (2009) adalah untuk memberikan tanggung jawab dan dorongan kepada karyawa dalam rangka meningkatkan kualitas dan kuantitas hasil kerjanya .

Insentif juga merupakan salah satu metode pengembangan karyawan, hal ini seperti dijelaskan oleh Hasibuan (2001) dalam Herman (2011), bahwa metode-metode yang diperlukan 
dalam pengembangan karyawan adalah:

1. Komunikasi, melalui komunikasi yang baik maka segala yang terjadi di perusahaan dapat terselesaikan dengan baik.

2. Insentif, dengan insentif karyawan, maka karyawan menjadi lebih bersemangat dalam bekerja.

3. Kesejahteraan karyawan, pemberian kesejahteraan meningkatkan loyalitas karyawan terhadap perusahaan.

4. Kesehatan dan keselamatan kerja, hal ini akan terwujud jika pemeliharaan karyawan berlangsung baik.

5. Hubungan industri pancasila, hubungan antar karyawan, pengusaha, dan pemerintah harus didasarkan pada nilai-nilai yang merupakan manifestasi sila-sila pancasila dan UUD 1945.

Yuniarsih dan Suwatno (2008) membagi jenis-jenis insentif menjadi beberapa kelompok, yaitu: (1) menurut pengaruh yang diberikan terhadap pemenuhan kepuasan, insentif dibagi menjadi Insentif Positif, yaitu segala sesuatu yang diterima sebagai imbalan yang dapat meningkatkan kepuasan dalam memenuhi kebutuhan individual dan Insentif Negatif, yaitu segala sesuatu yang diterima sebagai imbalan yang dapat menurunkan kepuasan dalam memenuhi kebutuhan individual; (2) menurut metode pemberiannya, insentif dibagi menjadi Insentif Formal, yaitu insentif yang ditetapkan berdasarkan tujuan, wewenang, tanggung jawab, standar, metode dan frekuensi pengukuran kinerja tertentu secara formal dan Insentif Informal, yaitu insentif yang didasarkan atas pengakuan kinerja dari kelompoknya; (3) menurut bentuknya, insentif dibagi menjadi Insentif Finansial, yaitu insentif yang diberikan dalam bentuk uang atau bermakna moneter.

Jenis-jenis insentif dalam suatu perusahaan/ instansi, harus dituangkan secara jelas sehingga dapat diketahui oleh pegawai dan oleh perusahaan tersebut dapat dijadikan kontribusi yang baik untuk dapat menambah gairah kerja bagi pegawai yang bersangkutan. Menurut ahli manaje- men sumber daya manusia Sondang P. Siagian (2002), jenis-jenis insentif tersebut adalah:

\section{Piece work}

Piece work adalah teknik yang digunakan untuk mendorong kinerja kerja pegawai berdasarkan hasil pekerjaan pegawai yang dinyatakan dalam jumlah unit produksi.

\section{Bonus}

Bonus adalah insentif yang diberikan kepada pegawai yang mampu bekerja sedemikian rupa sehingga tingkat produksi yang baku terlampaui.

\section{Komisi}

Komisi adalah bonus yang diterima karena berhasil melaksanakan tugas dan sering diterapkan oleh tenaga-tenaga penjualan.

\section{Insentif bagi eksekutif}

Insentif bagi eksekutif ini adalah insentif yang diberikan kepada pegawai khususnya manajer atau pegawai yang memiliki kedudukan tinggi dalam suatu perusahaan, misalnya untuk membayar cicilan rumah, kendaraan bermotor atau biaya pendidikan anak.

\section{Kurva "kematangan"}

Adalah diberikan kepada tenaga kerja yang karena masa kerja dan golongan pangkat serta gaji tidak bisa mencapai pangkat dan penghasilan yang lebih tinggi lagi, misalnya dalam bentuk penelitian ilmiah atau dalam bentuk beban mengajar yang lebih besar dan sebagainya.

\section{Rencana insentif kelompok}

Rencana insentif kelompok adalah kenyataan bahwa dalam banyak organisasi, kinerja bukan karena keberhasilan individual melainkan karena keberhasilan kelompok kerja yang mampu bekerja sebagai suatu tim.

Menurut Sutrisno (2011) tujuan dari insentif adalah sebagai berikut:

1. Menghargai suatu prestasi kerja

2. Keadilan terjamin

3. Karyawan dapat dipertahankan 
4. Karyawan bermutu akan didapat

5. Pengendalian biaya

6. Memenuhi peraturan

Tujuan memberikan insentif adalah:

1. Agar tenaga kerja yang terampil dan cakap agar mempunyai loyalitas tinggi terhadap perusahaan bisa dipertahankan.

2. Mempertahankan dan meningkatkan moral kerja pengawai yang ditunjukkan akan menurunnya tingkat perputaran tenaga kerja dan absensi

3. Produktivitas perusahaaan meningkat yang artinya hasil produksi bertambah untuk setiap unit per satuan waktu dan penjualan yang meningkat.

Menurut Sarwoto (2010: 156) indikator insentif dapat dibagi menjadi dua golongan, yaitu:

\section{Insentif Material}

1. Insentif Dalam Bentuk Uang

a) Bonus yang diberikan sebagai balas jasa atas hasil kerja yang telah dilaksanakan. Biasanya pemberiannya secara selektif dan khusus kepada karyawan yang berhak menerima dan diberikan secara sekali terima tanpa suatu ikatan di masa yang akan datang.

b) Komisi merupakan jenis bonus yang dibayarkan kepada pihak yang menghasilkan penjualan yang baik, biasanya dibayarkan kepada bagian penjualan dan diterimakan kepada pekerjanya bagian penjualan.

c) Profit share adalah salah satu jenis insentif tertua. Sistem pembayarannya berupa sebagian dari laba bersih yang disetorkan kedalam sebuah dana dan kemudia dimasukkan kedalam daftar pendapatan setia peserta.

d) Kompensai program balas jasa yang meliputi pembayaran di kemudia hari.

2. Insentif dalam bentuk jaminan sosial: insentif ini sering kali diberikan secara kolektif, tanpa unsur kompetitif dan setiap karyawan dapat memperolehnya se- cara sama rata dan otomatis. Bentuknya antara lain:

a) Pembuatan rumah dinas

b) Pengobatan secara gratis

c) Berlangganan surat kaar secara gratis

d) Biaya pindah

e) Cuti sakit yang tetap mendapatkan gaji pembayaran

f) Pemberian tugas belajar untuk mengembangkan pengetahuan karyawan

\section{Faktor-Faktor Yang Mempengaruhi Insentif}

Menurut Suwatno dan Donni (2011) faktor-faktor yang mempengaruhi besarnya insentif mencakup dua hal, yaitu: (1) jabatan atau kedudukan, seseorang yang menduduki jabatan atau kedudukan lebih tinggi di dalam suatu perusahaan otomatis tanggung jawab dan ruang lingkup kerjanya lebih besar atau sangat berpengaruh bagi roda kegiatan atau usaha suatu perusahaan itu, maka perusahaan dalam memberikan insentif harus melihat seberapa besar tugas dan tanggung jawab yang diemban oleh seorang karyawan yaitu apabila jabatan atau kedudukan karyawan lebih besar atau lebih tinggi maka perusahaan tersebut dalam memberikaan insentif lebih besar dari karyawan yang lainnya; (2) prestasi kerja, karyawan yang mempunyai prestasi kerja yang baik atau menonjol akan diberikan insentif yang lebih baik dan lebih besar daripada karyawan yang memiliki prestasi kerja yang kurang atau tidak menonjol. Oleh sebab itu, maka karyawan yang prestasi kerjanya kurang atau tidak menonjol akan lebih giat dan bersemangat dalam melakukan suatu pekerjaan agar organisasi dapat memberikan insentif yang lebih besar dan lebih baik.

\section{Kinerja}

Kinerja merupakan prestasi nyata yang ditampilkan seseorang setelah yang bersangkutan menjalankan tugas dan perannya dalam organisasi. Kinerja (performance) menurut Bangun (2012) adalah hasil pekerjaan yang dicapai seseorang berdasarkan persyaratan-persyaratan 
pekerjaan (job requirement).Kinerja merupakan suatu kegiatan yang dilakukan untuk melaksanakan, menyelesaikan tugas dan tanggung jawab sesuai dengan harapan dan tujuan yang telah ditetapkan(Supardi, 2014). Kinerja produktif merupakan tingkatan prestasi yang menunjukkan hasil guna yang tinggi. Muchdarsyah Sinungan, (2007), menegaskan bahwa "ketercapaian kinerja produktif perlu ditunjang oleh kemauan kerja yang tinggi, kemampuan kerja yang sesuai dengan isi kerja, lingkungan kerja yang nyaman, penghasilan yang dapat memenuhi kebutuhan hidup minimum, jaminan sosial yang memadai kondisi kerja yang manusiawi dan hubungan kerja yang harmonis". Hadari Nawawi (2008), mengemukakan bahwa "kinerja adalah hasil pelaksanaan suatu pekerjaan, baik bersifat fisik/ material maupun nonfisik/nonmaterial. Setiap pekerja dalam melaksanakan tugas-tugasnya sebagaimana terdapat didalam pekerja/jabatan perlu dinilai hasil kerja.

Sedangkan menurut Mangkunegara (2012) Kinerja karyawan (prestasi kerja) adalah hasil kerja secara kualitas dan kuantitas yang dicapai oleh seseorang karyawan dalam melaksanakan tugasnya sesuai dengan tanggung jawab yang diberikan kepadanya.

\section{Kinerja Guru}

Menurut undang-undang No. 14 Tahun 2005 tantang Guru dan Dosen Pasal 1 ayat (1), guru adalah pendidik profesional dengan tugas utama mendidik, mengajar, membimbing, mengarahkan, melatih, menilai dan mengevaluasi peserta didik pada pendidikan usia dini, pendidikan dasar, dan pendidikan menengah. Guru sebagai pendidik menurut Sagala (2013: 6) adalah tokoh yang paling banyak bergaul dan berinteraksi dengan para murid dibandingkan dengan para personel lainnya di sekolah. Guru bertugas merencanakan dan melaksanakan proses pembelajaran, menilai hasil pembelajaran, melakukan bimbingan dan pelatihan, melakukan penelitian dan pengkajian, dan membuka komunikasi dengan masyarakat.
Kinerja guru menurut Supardi (2014: 54) merupakan kemampuan seorang guru dalam melaksanakan tugas pembelajaran di madrasah dan bertanggung jawab atas peserta didik di bawah bimbingannya dengan meningkatkan prestasi belajar peserta didik. Oleh karena itu, kinerja guru itu dapat diartikan sebagai suatu kondisi yang menunjukkan kemampuan seorang guru dalam menjalankan tugasnya di madrasah serta menggambarkan adanya suatu perbuatan ang ditampilkan guru dalam atau selama melakukan aktivitas pembelajaran. Guru yang memiliki kinerja baik dan profesional dalam implementasi kurikulum memiliki ciri-ciri: mendesain program pembelajaran, melaksanakan pembelajaran dan menilai hasil belajar peserta didik Supardi, (2014) mengutip Basyirudin dan Usman, (2002).

\section{Faktor yang mempengaruhi Kinerja Guru}

Selanjutnya A. Tabrani Rusyan dkk (2000:17) menyatakan bahwa untuk mendukung keberhasilan Kinerja guru seperti diterangkan di atas, maka perlu berbagai faktor yang mendukung, di antaranya:

1) Motivasi Kinerja Guru

Dorongan untuk melaksanakan pekerjaan dengan baik bagi guru sebaiknya muncul dari dalam diri sendiri, tetapi upaya motivasi dari luar juga dapat juga memberikan semangat kerja guru, misalnya dorongan yang diberikan dari kepala sekolah kepada guru.

2) Etos Kinerja Guru

Guru memiliki etos kerja yang lebih besar untuk berhasil dalam melaksanakan proses belajar mengajar dibandingkan dengan guru yang tidak ditunjang oleh etos Kinerja.dalam melaksanakan tugasnya guru memiliki etos yang berbeda-beda. Etos kerja perlu dikembangkan oleh guru, karena:

a) Pergeseran waktu yang mengakibatkan segala sesuatu dalam kehidupan manusia berubah dan berkembang. 
b) Kondisi yang terbuka untuk menerima dan menyalurkan kreativitas.

c) Perubahan lingkungan terutama bidang teknologi.

3) Lingkungan Kinerja guru

Lingkungan kerja yang dapat mendukung guru melaksanakan tugas secara efektif dan efisien, meliputi:

a) Lingkungan social-psikologis, yaitu lingkungan serasi dan harmonis antarguru, guru dengan kepala sekolah, dan guru, kepala sekolah, dengan staf TU dapat menunjang berhasilnya Kinerja guru.

b) Lingkungan fisik, ruang Kinerja guru hendaknya memenuhi syaratsyarat sebagai berikut: (1) Ruangan harus bersih, (2) Ada ruangan khusus untuk kerja, (3) Peralatan dan perabotan tertata baik, (4) Mempunyai penerangan yang baik, (5) Tersedia meja kerja yang cukup, (6) Sirkulasi udara yang baik, dan (7) Jauh dari kebisingan.

Tugas dan tanggung jawab guru sebagai berikut:

a) Tanggung jawab moral, guru harus memiliki kemampuan menghayati perilaku dan etika yang sesuai dengan moral Pancasila.

b) Tanggung jawab dan proses pembelajaran di sekolah, yaitu setiap guru harus menguasai cara pembelajaran yang efektif, mampu membuat persiapan mengajar dan memahami kurikulum dengan baik.

c) Tanggung jawab guru di bidang kemasyarakatan, yaitu turut mensukseskan pembangunan masyarakat, untuk itu guru harus mampu membimbing, mengabdi, dan melayani masyarakat.

d) Tanggung jawab guru di bidang keilmuan, yaitu guru turut serta memajukan ilmu dengan melaksanakan penelitian dan pengembangan.

e) Optimalisasi kelompok kerja guru

Kinerja guru yang efektif dan efisien akan menghasilkan sumber daya manusia yang tangguh, yaitu lulusan yang berdaya guna dan berhasil guna sesuai dengan tujuan yang telah ditetapkan. Oleh karena itu, Kinerja guru dalam proses pembelajaran perlu ditingkatkan sebagai upaya mengembangkan kegiatan yang ada menjadi lebih baik, yang berdasarkan kemampuan bukan kepada asal-usul keturunan atau warisan, juga menjunjung tinggi kualitas, inisiatif dan kreativitas, kerja keras dan produktivitas.

Kinerja seorang karyawan dapat dipengaruhi berbagai faktor, baik faktor eksternal maupun internal dari karyawan tersebut. Simamora dalam Mangkunegara (2012) mengatakan bahwa kinerja pada umum nya dipengaruhi oleh tiga faktor, yaitu:

a. Faktor individual yang terdiri dari:
1) Kemampuan dan keahlian
2) Latar belakang
3) Demografi

b. Faktor psikologis yang terdiri dari:
1) Persepsi
2) Attitude
3) Personality
4) Pembelajaran
5) Motivasi

c. Faktor organisasi yang terdiri dari:

1) Sumber daya

2) Kepemimpinan

3) Penghargaan

4) Struktur

5) Job Design

Setiap perusahaan memiliki indikator yang berbeda-beda dalam menilai kinerja para karyawannya. Hasibuan (2012) mengemukakan terdapat beberapa indikator umum yang berkaitan dengan kinerja, yaitu:

1. Ketepatan hasil kerja

2. Ketelitian hasil kerja

3. Hasil kerja yang dihasilkan

4. Kehadiran

5. Peraturan perusahaan

6. Kecepatan waktu kerja

7. Bekerja sama

8. Komunikasi 


\section{HIPOTESIS PENELITIAN}

Terdapat pengaruh insentif terhadap kinerja guru pada SMK Mulia Buana Bogor. Adapun hipotesis dalam penelitian ini sebagai berikut:

$H_{O}=0$ : Tidak terdapat pengaruh yang signifikan insentif terhadap kinerja guru pada SMK Mulia Buana Bogor.

$H_{1} \neq 0$ : Terdapat pengaruh yang signifikan insentif terhadap kinerja guru pada SMK Mulia Buana Bogor.

\section{METODE PENELITIAN}

\section{Variabel Penelitian}

Variabel bebas (Variabel X) dalam penelitian ini adalah insentif pada SMK Mulia Buana Bogor.

Variabel terikat (Variabel Y) dalam penelitian ini adalah Kinerja Guru pada SMK Mulia Buana Bogor.

\section{Populasi Dan Sampel}

Penelitian ini menggunakan sampel jenuh, Populasi penelitian ini adalah para Guru, seluruh Guru SMK Mulia Buana Bogor yang berjumlah 52 orang Guru.

\section{Metode Analisis Data}

Dalam Penelitian ini metode analisis data yang digunakan sebagai berikut:

\section{Uji Validitas}

Teknik yang digunakan untuk menguji validitas kuesioner adalah menggunakan rumus korelasi product moment sebagai berikut:

$$
r x y=\frac{\left(\mathrm{n} \sum \mathrm{xy}\right)-\left(\sum \mathrm{x}\right)\left(\sum \mathrm{y}\right)}{\sqrt{\left\{\left(\mathrm{n} \sum \mathrm{x}^{2}\right)-\left(\sum \mathrm{x}\right)^{2}\right\}\left\{\mathrm{n} \sum \mathrm{y}^{2}-\left(\sum \mathrm{y}\right)^{2}\right\}}}
$$

\section{Keterangan:}

rxy= koifisien korelasi

$\Sigma \mathrm{Xi}=$ Jumlah skor item

$\sum Y \mathrm{Y}=$ Jumlah skor total (seluruh item)

$\mathrm{N}=$ Jumlah responden

Kriteria: $r$ hitung $>\mathrm{r}$ table $=$ Valid

\section{Uji Reliabilitas}

Cara yang digunakan untuk menguji realibilitas kuesioner adalah dengan menggunakan rumus cronbach alpha:

$$
\sigma=\frac{K}{K-1}\left(1-\frac{\sum_{i}^{K} \sigma_{Y_{i}}^{2}}{\sigma_{X}^{2}}\right)
$$

Keterangan:

$\mathrm{R}=$ koefisien realibilitas instrument (cronbach alpha)

$\mathrm{K}$ = banyaknya butir pertanyaan atau banyaknya soal

$\sum_{i}^{K}=$ total varians butir

$\sigma_{X}^{2}=$ total varians

Kriteria: $r$ hitung $>r$ table

\section{Koifisien Korelasi (r)}

Untuk dapat mengetahui pengaruh disiplin kerja terhadap kinerja Guru pada SMK Mulia Buana Bogor. Penulis menganalisa dengan menggunakan metode koefisien korelasi yang dapat dirumuskan sebagai berikut :

$$
r x y=\frac{n \sum X Y-\sum X \cdot \sum Y}{\sqrt{\left\{n \sum X^{2}-\left(\sum x\right)^{2} n \sum y^{2}-\left(\sum y\right)^{2}\right\}}}
$$

Keterangan :

$\mathrm{r}=$ Koefisien Korelasi

$\mathrm{X}=$ Variabel independen (Insentif)

$\mathrm{Y}=$ Variabel dependen (Kinerja Guru)

X2 = Jumlah kuadrat seluruh Variabel X

Y2 = Jumlah Kuadrat Seluruh Variabel Y

$\mathrm{n}=$ Jumlah Responden

Table 3.1

Pedoman untuk memberikan interprestasi koefisien korelasi

\begin{tabular}{|c|c|}
\hline Interval koefisen & Tingkat hubungan \\
\hline $0,0-0,199$ & Sangat rendah \\
$0,20-0,399$ & Rendah \\
$0,40-0,599$ & Sedang \\
$0,60-0,799$ & Kuat \\
$0,80-1,000$ & Sangat kuat \\
\hline
\end{tabular}

Sumber: Sugiyono (2009:250) 


\section{Koefisien Determinasi}

Untuk mengetahui sejauh mana hubungan antara besarnya insentif dengan kinerja Guru dihitung dengan rumus uji koefisien determinasi sebagai berikut :

$\mathrm{KD}=\mathrm{r}^{2} \times 100 \%$

Dimana :

$\mathrm{KD}=$ Koefisien Determinasi

$\mathrm{r}^{2}=$ koefisien korelasi parsial

\section{Uji Hipotesis}

Yaitu pengujian koefisien regresi parsial individual yang digunakan untuk mengetahui apakah variabel $(\mathrm{X})$ secara individual mempengaruhi langkah-langkah variabel (Y). Uji signifikan ini menggunakan rumus uji t yaitu :

$$
t=\frac{r \sqrt{n-2}}{\sqrt{1-r^{2}}}
$$

Dimana :

$\mathrm{t}=$ nilai uji $\mathrm{t}$

$\mathrm{r}=$ koefisien korelasi

$\mathrm{n}$ = banyak sample

Tingkat Signifikansi

$a=5 \%$

$\mathrm{t}(\mathrm{db}=\mathrm{n}-2)$

Kaidah Pengujian:

Jika t hitung $\geq \mathrm{t}$ table, maka signifikan

Jika $\mathrm{t}$ hitung $\leq \mathrm{t}$ table, maka tidak signifikan

\section{Operasional Variabel Penelitian}

Variabel penelitian merupakan konsep yang memiliki bermacam-macam nili atau gejala yang bervariasi. Dalam penelitian ini, digunakan dua jenis variabel, yaitu:

Variabel Independen, yaitu variable insentif. Disebut juga variabel $(\mathrm{x})$ dan merupakan varibel bebas yang diukur dengan skala ordinal dari likert.

Variabel dependen, yaitu variable kinerja guru. Disebut juga sebagai varibel (y) dan merupakan varibel terikat yang diukur dengn skala ordinal likert.

Untuk penjabaran variable insentif dan kinerja dapat dilihat pada table dibawah ini:
Tabel 3.1

Penjabaran Operasional Variabel X Konsep Variabel Variabel Indikator Variabel

\begin{tabular}{|c|c|c|}
\hline $\begin{array}{l}\text { Insentif adalah bentuk } \\
\text { penghargaan yang diberikan } \\
\text { organisasi/ perusahaan } \\
\text { yang dikaitkan dengan } \\
\text { kinerja sebagai pembagian } \\
\text { keuntungan baik dalam } \\
\text { bentuk financial maupun non } \\
\text { finansial }\end{array}$ & Insentif & $\begin{array}{l}\text { a. Kinerja } \\
\text { b. Lama kerja } \\
\text { c. Senioritas } \\
\text { d. Kebutuhan } \\
\text { e. Keadilan dan } \\
\text { kelayakan } \\
\text { f. Evaluasi jabatan }\end{array}$ \\
\hline
\end{tabular}

Tabel 3.2

Penjabaran Operasional Variabel Y

\begin{tabular}{|c|c|}
\hline Konsep Variabel & Variabel \\
\hline
\end{tabular}

\begin{tabular}{l|l|l} 
kemampuan seorang guru & Kinerja & a. Loyalitas
\end{tabular}

dalam melaksanakan tugas Guru b. Semangat Kerja

pembelajaran di madrasah $\quad$ c. Kepemimpinan

dan bertanggung jawab $\quad$ d. Kerjasama

atas peserta didik di bawah $\quad$ e. Prakarsa

bimbingannya dengan $\quad$ f. Tanggung

meningkatkan prestasi

belajar peserta didik.

g. Pencapaian Target

\section{HASIL PENELITIAN DAN PEMBAHASAN \\ HASIL PENELITIAN \\ Insentif $(X)$}

Adapun hasil Jawaban dari 52 orang responden terhadap variabel insentif yang terdiri dari 12 pernyataan, jawaban yang diperoleh kemudian dianalisa dengan menggunakan metode prosentase jawaban, Data hasil penyebaran 12 pernyataan tentang insentif yang diberikan kepada responden, peneliti dapat menganalisa persentase jawaban dari total jawaban masing-masing skala dibagi dengan total keseluruhan jawaban kuesioner, dimana total jawaban adalah $194+243+164+23+0=624$ atau :

Berdasarkan jawaban responden tersebut maka peneliti menyimpulkan bahwa sebagian besar tanggapan responden menilai 31,09\% "Sangat Setuju" dan 38,98\% "Setuju" bahwa insentif (X) pada SMK Mulia Buana Bogor sudah baik.

\section{Variabel Kinerja Guru (Y)}

Data hasil variabel kinerja guru $(\mathrm{Y})$ yang diperoleh melalui kuesioner terhadap 52 orang guru pada SMK Mulia Buana Bogor, Data hasil penyebaran 14 pernyataan tentang kinerja guru 
yang diberikan kepada responden, peneliti dapat menganalisa persentase jawaban dari total jawaban masing-masing skala dibagi dengan total keseluruhan jawaban kuesioner, dimana total jawaban adalah $250+261+182+30+0$ $=723$ atau :

Berdasarkan jawaban responden tersebut maka peneliti menyimpulkan bahwa sebagian besar tanggapan responden menilai 34,58\% "Sangat Setuju" dan 36,10\% "Setuju" bahwa Kinerja Guru (Y) pada SMK Mulia Buana Bogor sudah baik.

\section{Uji Validitas}

Diketahui bahwa :

$$
\mathrm{N}=52
$$

$\mathrm{S} X=221$

$S \mathrm{Y}=2480$

$\mathrm{S} \mathrm{X} 2=971$

$\mathrm{S} Y 2=119346$

$\mathrm{S} X . \mathrm{Y} 2=10627$

$\mathrm{rx}=\frac{n \sum x y-\left(\sum x\right)\left(\sum y\right)}{\sqrt{\left[n \sum x^{2}-\left(\sum x\right)^{2}\right]\left[n \sum y^{2}-\left(\sum y\right)^{2}\right]}}$

$$
\mathrm{r}=\frac{52(10627)-(221) \cdot(2480)}{\sqrt{\left(52.971-(221)^{2} \cdot(52.119346)-(2480)^{2}\right.}}
$$

$r=\frac{552604-548080}{\sqrt{(50492-48841) \cdot(6205992-6150400)}}$

$\mathrm{r}=\frac{4524}{\sqrt{(1651) \cdot(55592)}}$

$\mathrm{r}=\frac{4524}{\sqrt{91782392}}$

$r=\frac{4524}{9580,31273}$

$r=0,472218405$ dibulatkan menjadi 0,472 dst.......sampai butir pernyataan ke-12.

Berdasarkan perhitungan diatas dapat diketahui bahwa rhitung, $(0,472)>\operatorname{rtabel}(0,231)$, berarti butir pernyataan nomor 1 dinyatakan valid.
Tabel 4.1

Hasil Analisis Item Instrumen Insentif (X)

\begin{tabular}{|c|c|c|c|}
\hline Butir Instrumen & $\mathbf{r}_{\text {hitung }}$ & $\mathbf{r}_{\text {tabel }}$ & Keterangan \\
\hline 1 & 0,472 & 0,231 & Valid \\
\hline 2 & 0,308 & 0,231 & Valid \\
\hline 3 & 0,476 & 0,231 & Valid \\
\hline 4 & 0,319 & 0,231 & Valid \\
\hline 5 & 0,45 & 0,231 & Valid \\
\hline 6 & 0,613 & 0,231 & Valid \\
\hline 7 & 0,499 & 0,231 & Valid \\
\hline 8 & 0,395 & 0,231 & Valid \\
\hline 9 & 0,508 & 0,231 & Valid \\
\hline 10 & 0,297 & 0,231 & Valid \\
\hline 11 & 0,517 & 0,231 & Valid \\
\hline 12 & 0,568 & 0,231 & Valid \\
\hline
\end{tabular}

Sumber : Data yang diolah 2017

Dari tabel diatas dapat dilihat bahwa dari nilai keseluruhan koefisien korelasi (rhitung) memiliki nilai yang lebih besar daripada (rtabel) atau rhitung lebih besar dari 0,231. Oleh karena itu, dapat disimpulkan bahwa ke 12 pernyataan tersebut adalah valid. Butir yang memiliki validitas tertinggi adalah butir ke enam yaitu 0,613 dan paling rendah adalah butir ke sepuluh yaitu 0,297.

Sedangkan hasil perhitungan uji validitas untuk kinerja guru terlihat pada tabel 4.2 dibawah ini:

Dari perhitungan rhitung didapatkan hasil sebagai berikut:

Tabel 4.2

Hasil Analisis Item Instrumen Kinerja Guru (Y)

\begin{tabular}{|c|c|c|c|}
\hline Butir Instrumen & $\mathbf{r}_{\text {hitung }}$ & $\mathbf{r}_{\text {tabel }}$ & Keterangan \\
\hline 1 & 0,425 & 0,231 & Valid \\
\hline 2 & 0,383 & 0,231 & Valid \\
\hline 3 & 0,584 & 0,231 & Valid \\
\hline 4 & 0,329 & 0,231 & Valid \\
\hline 5 & 0,298 & 0,231 & Valid \\
\hline 6 & 0,443 & 0,231 & Valid \\
\hline 7 & 0,433 & 0,231 & Valid \\
\hline 8 & 0,495 & 0,231 & Valid \\
\hline 9 & 0,341 & 0,231 & Valid \\
\hline 10 & 0,647 & 0,231 & Valid \\
\hline
\end{tabular}




\begin{tabular}{|c|c|c|c|}
\hline Butir Instrumen & $\mathbf{r}_{\text {hitung }}$ & $\mathbf{r}_{\text {tabel }}$ & Keterangan \\
\hline 11 & 0,482 & 0,231 & Valid \\
\hline 12 & 0,445 & 0,231 & Valid \\
\hline 13 & 0,495 & 0,231 & Valid \\
\hline 14 & 0,647 & 0,231 & Valid \\
\hline
\end{tabular}

Sumber : Data yang diolah 2017

Dari tabel tersebut dapat dilihat bahwa dari nilai keseluruhan korelasi (rhitung) memiliki nilai yang lebih besar daripada(rtabel) atau rhitung lebih besar dari 0,231. Oleh karena itu, dapat disimpulkan bahwa ke 14 pernyataan tersebut adalah valid. Butir yang memiliki validitas tertinggi adalah butir ke sepuluh dan empat belas yaitu 0,647 dan paling rendah adalah butir ke lima yaitu sebesar 0,298.

\section{Uji Realibilitas}

Uji relibiilitas dilakukan dengan melihat nilai Alpha Cronbach dengan kriteria sebagai berikut:

a. Jika nilai Alpha Cronbach > 0,60 maka suatu variabel dikatakan reliable.

b. Jika nilai Alpha Cronbach $<0,60$ maka suatu variabel dikatakan tidak reliable.

Berikut hasil pengukuran uji reliabilitas dari kedua variabel yakni insentif dan kinerja guru sebagai berikut:

Variabel X (Insentif)

$$
\begin{aligned}
& \mathrm{Si}=\frac{\sum X i^{2}-\frac{\left(\sum X i\right)^{2}}{n}}{n} \\
& \mathrm{Si}=\frac{971-\frac{(221)^{2}}{52}}{52}=0,611
\end{aligned}
$$

Tabel 4.3

Hasil Analisis

Uji Realibilitas Insentif (X)

\begin{tabular}{|c|c|c|}
\hline Butir Instrumen & Keterangan & Si \\
\hline 1 & $\mathrm{~S}_{1}$ & 0,611 \\
\hline 2 & $\mathrm{~S}_{2}$ & 0,615 \\
\hline 3 & $\mathrm{~S}_{3}$ & 0,634 \\
\hline 4 & $\mathrm{~S}_{4}$ & 0,643 \\
\hline 5 & $\mathrm{~S}_{5}$ & 0,763 \\
\hline
\end{tabular}

\begin{tabular}{|c|c|c|}
\hline Butir Instrumen & Keterangan & Si \\
\hline 6 & $\mathrm{~S}_{6}$ & 0,707 \\
\hline 7 & $\mathrm{~S}_{7}$ & 0,611 \\
\hline 8 & $\mathrm{~S}_{8}$ & 0,98 \\
\hline 9 & $\mathrm{~S}_{9}$ & 0,664 \\
\hline 10 & $\mathrm{~S}_{10}$ & 0,617 \\
\hline 11 & $\mathrm{~S}_{11}$ & 0,771 \\
\hline 12 & $\mathrm{~S}_{12}$ & 0,768 \\
\hline
\end{tabular}

Total Varian skor tiap butir pertanyaan $\Sigma \mathrm{Si}=8,383$

$$
\begin{aligned}
& \mathrm{St}=\frac{\sum X t^{2}-\frac{\left(\sum X t\right)^{2}}{n}}{n} \\
& \mathrm{St}=\frac{119346-\frac{(2480)^{2}}{52}}{52}=20,615 \\
& r c a=\frac{k}{k-1}\left(1-\frac{\Sigma S i}{S t}\right) \\
& \mathrm{rca} \frac{12}{12-1}\left(1-\frac{8,383}{20,615}\right)=0,648
\end{aligned}
$$

Uji Realibilitas variabel Y (Kinerja Guru), dengan menggunakan metode cronbach alpha:

$$
\begin{aligned}
& \mathrm{Si}= \\
& \mathrm{Si}==0,697 \ldots \ldots \ldots . . \mathrm{Si} 14=0,802
\end{aligned}
$$

Tabel 4.4

Hasil Analisis Uji Realibilitas Kinerja (Y)

\begin{tabular}{|c|c|c|}
\hline Butir Instrumen & Keterangan & Si \\
\hline 1 & $\mathrm{~S}_{1}$ & 0,697 \\
\hline 2 & $\mathrm{~S}_{2}$ & 0,641 \\
\hline 3 & $\mathrm{~S}_{3}$ & 0,851 \\
\hline 4 & $\mathrm{~S}_{4}$ & 0,788 \\
\hline 5 & $\mathrm{~S}_{5}$ & 0,794 \\
\hline 6 & $\mathrm{~S}_{6}$ & 0,648 \\
\hline 7 & $\mathrm{~S}_{7}$ & 0,779 \\
\hline 8 & $\mathrm{~S}_{8}$ & 0,827 \\
\hline 9 & $\mathrm{~S}_{9}$ & 0,578 \\
\hline 10 & $\mathrm{~S}_{10}$ & 0,802 \\
\hline 11 & $\mathrm{~S}_{11}$ & 0,729 \\
\hline 12 & $\mathrm{~S}_{12}$ & 0,708 \\
\hline 13 & $\mathrm{~S}_{13}$ & 0,827 \\
\hline 14 & $\mathrm{~S}_{14}$ & 0,802 \\
\hline
\end{tabular}


Total Varian skor tiap butir pertanyaan $\Sigma \mathrm{Si}=10,47$

$\mathrm{St}=\frac{\sum X t^{2}-\frac{\left(\sum X t\right)^{2}}{n}}{n}$<smiles>CC(C)[Mg][Mg]</smiles>

$=31,365$

$r c a=\frac{k}{k-1}\left(1-\frac{\Sigma S i}{S t}\right)$

$=\frac{14}{14-1}\left(1-\frac{10,47}{31,365}\right)$

$=0,717$

Tabel dan perhitungan diatas menunjukan nilai Alpha Cronbach atas variabel intensif 0,648 dan kinerja karyawan 0,717 . Dengan demikian dapat ditarik kesimpulan bahwa pernyataan dalam kuesioner ini realibel karena mempunyai Alpha Cronbach lebih besar dari 0,60. Hal ini menunjukan bahwa setiap item pernyataan yang digunakan akan mampu memperoleh data yang konsisten yang berarti bila pernyataan itu diajukan kembali akan diperoleh jawaban yang relative sama dengan jawaban sebelumnya.

\section{Hasil Analisis Penelitian dan Pembahasan}

\section{a. Analisis Koefisien Korelasi}

Setelah semua instrumen yang digunakan peneliti dilakukan pengujian validitas dan reliabilitas dan dinyatakan valid dan reliabel, langkah selanjutnya adalah melakukan analisis koefisien korelasi. Analisis koefisien korelasi dimaksudkan untuk mengukur keeratan hubungan (korelasi) antara dua variabel, yaitu variabel kompensasi terhadap kinerja karyawan. Perhitungan koefisien korelasi menggunakan rumus product momentdan didasarkan pada hasil penyebaran kuesioner sebagai berikut :

Tabel 4.5

Analisis Pengaruh Insentif Terhadap Kinerja Guru

\begin{tabular}{|c|c|c|c|c|c|}
\hline NO & $\mathbf{X}$ & $\mathbf{Y}$ & $\mathbf{X}^{2}$ & $\mathbf{Y}^{2}$ & $\mathbf{X Y}$ \\
\hline 1 & 47 & 55 & 2209 & 3025 & 2585 \\
\hline 2 & 47 & 52 & 2209 & 2704 & 2444 \\
\hline 3 & 42 & 53 & 1764 & 2809 & 2226 \\
\hline 4 & 49 & 55 & 2401 & 3025 & 2695 \\
\hline 5 & 48 & 58 & 2304 & 3364 & 2784 \\
\hline 6 & 52 & 57 & 2704 & 3249 & 2964 \\
\hline 7 & 51 & 58 & 2601 & 3364 & 2958 \\
\hline 8 & 50 & 62 & 2500 & 3844 & 3100 \\
\hline 9 & 55 & 58 & 3025 & 3364 & 3190 \\
\hline 10 & 53 & 60 & 2809 & 3600 & 3180 \\
\hline 11 & 50 & 59 & 2500 & 3481 & 2950 \\
\hline 12 & 43 & 46 & 1849 & 2116 & 1978 \\
\hline 13 & 53 & 63 & 2809 & 3969 & 3339 \\
\hline 14 & 47 & 55 & 2209 & 3025 & 2585 \\
\hline 15 & 39 & 48 & 1521 & 2304 & 1872 \\
\hline 16 & 53 & 58 & 2809 & 3364 & 3074 \\
\hline 17 & 48 & 57 & 2304 & 3249 & 2736 \\
\hline
\end{tabular}

\begin{tabular}{|c|c|c|c|c|c|}
\hline NO & $\mathbf{X}$ & $\mathbf{Y}$ & $\mathbf{X}^{2}$ & $\mathbf{Y}^{2}$ & $\mathbf{X Y}$ \\
\hline 18 & 50 & 56 & 2500 & 3136 & 2800 \\
\hline 19 & 48 & 61 & 2304 & 3721 & 2928 \\
\hline 20 & 48 & 51 & 2304 & 2601 & 2448 \\
\hline 21 & 44 & 54 & 1936 & 2916 & 2376 \\
\hline 22 & 49 & 56 & 2401 & 3136 & 2744 \\
\hline 23 & 48 & 53 & 2304 & 2809 & 2544 \\
\hline 24 & 44 & 53 & 1936 & 2809 & 2332 \\
\hline 25 & 48 & 56 & 2304 & 3136 & 2688 \\
\hline 26 & 43 & 49 & 1849 & 2401 & 2107 \\
\hline 27 & 47 & 58 & 2209 & 3364 & 2726 \\
\hline 28 & 45 & 53 & 2025 & 2809 & 2385 \\
\hline 29 & 48 & 61 & 2304 & 3721 & 2928 \\
\hline 30 & 51 & 50 & 2601 & 2500 & 2550 \\
\hline 31 & 51 & 62 & 2601 & 3844 & 3162 \\
\hline 32 & 50 & 53 & 2500 & 2809 & 2650 \\
\hline 33 & 46 & 60 & 2116 & 3600 & 2760 \\
\hline 34 & 49 & 57 & 2401 & 3249 & 2793 \\
\hline
\end{tabular}




\begin{tabular}{|c|c|c|c|c|c|}
\hline NO & $\mathbf{X}$ & $\mathbf{Y}$ & $\mathbf{X}^{2}$ & $\mathbf{Y}^{2}$ & $\mathbf{X Y}$ \\
\hline 35 & 40 & 51 & 1600 & 2601 & 2040 \\
\hline 36 & 44 & 64 & 1936 & 4096 & 2816 \\
\hline 37 & 51 & 56 & 2601 & 3136 & 2856 \\
\hline 38 & 44 & 57 & 1936 & 3249 & 2508 \\
\hline 39 & 45 & 64 & 2025 & 4096 & 2880 \\
\hline 40 & 51 & 63 & 2601 & 3969 & 3213 \\
\hline 41 & 52 & 62 & 2704 & 3844 & 3224 \\
\hline 42 & 47 & 49 & 2209 & 2401 & 2303 \\
\hline 43 & 36 & 48 & 1296 & 2304 & 1728 \\
\hline 44 & 43 & 66 & 1849 & 4356 & 2838 \\
\hline 45 & 54 & 62 & 2916 & 3844 & 3348 \\
\hline 46 & 56 & 64 & 3136 & 4096 & 3584 \\
\hline 47 & 53 & 67 & 2809 & 4489 & 3551 \\
\hline 48 & 54 & 55 & 2916 & 3025 & 2970 \\
\hline 49 & 41 & 41 & 1681 & 1681 & 1681 \\
\hline 50 & 52 & 53 & 2704 & 2809 & 2756 \\
\hline 51 & 44 & 45 & 1936 & 2025 & 1980 \\
\hline 52 & 37 & 51 & 1369 & 2601 & 1887 \\
\hline$\Sigma$ & 2480 & 2915 & 119346 & 165039 & 139744 \\
\hline$R \times y$ & & & 0.545 & & \\
\hline
\end{tabular}

Sumber : Data yang diolah 2017

Analisis koefisien korelasi product moment digunakan untuk menentukan bentuk dan jenis pengaruh korelasi antara variabel insentif dengan kinerja guru dimana rumus yang digunakan adalah sebagai berikut :

Keterangan :

$\mathrm{N}=52$

$\mathrm{SX}=2480$

$\mathrm{SY}=2915$

$\mathrm{X} 2=119346$

$\mathrm{Y} 2=165039$

SXY $=139744$

$$
\begin{aligned}
& \mathbf{r X y}=\frac{n \sum X Y-(\Sigma X)(\Sigma Y)}{\sqrt{\left\{n \sum X^{2}-(\Sigma X)^{2}\right\}\left\{n \Sigma Y^{2}-\left(\Sigma Y^{2}\right)^{2}\right\}}} \\
& \mathbf{r X y}=\frac{52.139744-(2480)(2915)}{\left.\sqrt{\left\{52.119346-(2480)^{2}\right\}\{52.165039}-(2915)^{2}\right\}} \\
& \mathbf{r X y}=\frac{7266688-7229200}{\sqrt{\{6205992-6150400\}\{8582028}-8497225\}} \\
& \mathbf{r X y}=\frac{37488}{\sqrt{(55592)(84803)}}
\end{aligned}
$$

$$
\begin{aligned}
& \mathbf{r x y}=\frac{37488}{\sqrt{4714368.376}} \\
& \mathbf{r x y}=\frac{37488}{68661,25819} \\
& \mathbf{r x y}=0,545984752 \\
& \mathbf{r x y}=0,546
\end{aligned}
$$

Berdasarkan hasil analisis dengan menggunakan rumus koefisien korelasi product moment yang didapat yaitu $\mathrm{r}=0,546$ yang berarti ada pengaruh yang sedang antara variabel insentif $(\mathrm{X})$ terhadap variabel kinerja guru $(\mathrm{Y})$ pada SMK Mulia Buana Bogor.

\section{b. Koefisien Determinasi}

Setelah mengukur hubungan antara kedua variabel tersebut dengan menggunakan koefisien korelasi product moment, maka langkah selanjutnya akan mencari koefisien determinasi (Kd) untuk mengukur seberapa besar kontribusi variabel $\mathrm{X}$ terhadap variabel $\mathrm{Y}$ yaitu :

$$
\begin{aligned}
& \mathrm{Kd}=\mathrm{r} 2 \times 100 \% \\
& \mathrm{Kd}=0,5462 \times 100 \% \\
& \mathrm{Kd}=29,81 \%
\end{aligned}
$$

Berdasarkan hasil perhitungan koefisien determinasi adalah 29,81\%, maka insentif memiliki pengaruh terhadap kinerja yaitu yaitu $29,81 \%$, dan sisanya sebesar $70,19 \%$ dipengaruhi oleh faktor-faktor lain.

\section{c. Uji Hipotesis (Uji t)}

Penulis melakukan pengujian hipotesis dengan cara membandingkan nilai ttabel dengan thitung. Nilai ttabel ditentukan berdasarkan tingkat signifikan $\left({ }^{\alpha \alpha}\right)$ yang digunakan dan derajat kebebasan $(\mathrm{df}=\mathrm{n}-2)$ yang besarnya tergantung dari jumlah sampel (n). Taraf nyata yang penulis gunakan sebesar 0,05 (5\%). Rumus $t$ hitung adalah sebagai berikut:

$t=\frac{r \sqrt{n-2}}{\sqrt{1-r^{2}}}$

Dimana:

$\mathrm{r}=$ koefisien korelasi

$\mathrm{n}=$ banyaknya responden 
Untuk mengetahui apakah insentif memiliki keberartian dalam meningkatkan kinerja guru perlu dilakukan uji signifikasi korelasi dengan menggunakan uji-t, maka hipotesis dalam penelitian ini adalah:

Ho $: r=0$ : Tidak terdapat pengaruh yang positif dan signifikan antara insentif terhadap kinerja guru pada SMK Mulia Buana Bogor

Ha $: r \neq 0:$ Terdapat pengaruh yang positif dan signifikan antara insentif terhadap kinerjaguru pada SMK Mulia Buana Bogor

Kriteria penguji :

1. Jika $t_{\text {hitung }}>t_{\text {tabel }}$, maka Ho ditolak dan H1 diterima.

2. Jika $\mathrm{t}_{\text {hitung }} \mathrm{g}<\mathrm{t}_{\text {tabel }}$ maka Ho diterima dan $\mathrm{H} 1$ ditolak.

$$
\begin{aligned}
& t_{\text {hitung }}=\frac{r \sqrt{n-2}}{\sqrt{1-r^{2}}} \\
& t_{\text {hitung }}=\frac{0,546 \sqrt{52-2}}{\sqrt{1-0,546^{2}}} \\
& t_{\text {hitung }}=\frac{0,546 \sqrt{50}}{\sqrt{1-0,298116}} \\
& t_{\text {hitung }}=\frac{0,546 \times 7,071}{\sqrt{0,701884}} \\
& t_{\text {hitung }}=\frac{3,860766}{0,837785} \\
& t_{\text {hitung }}=4,60830
\end{aligned}
$$

dibulatkan menjadi 4,6

Mencari ttabel :

$\mathrm{t}_{\text {tabel }}=\left(\begin{array}{c}\alpha \alpha ; \mathrm{n}-2) \\ 0,050,05\end{array}\right.$

$\mathrm{t}_{\text {tabel }}=\left(\frac{0,050,05}{0} ; 52-2\right)$

$\mathrm{t}_{\text {tabel }}=\left({ }^{0,050,05} ; 50\right)$

$\mathrm{t}_{\text {tabel }}=1,67$

Berdasarkan hasil perhitungan dari penelitian diatas, maka dapat diberikan uji hipotesis sebagai berikut :

Ho ditolak dan H1 diterima, karena thitung $>$ ttabel $(4,6>1,67)$, berarti bahwa koefisien korelasi antara $\mathrm{X}$ dan $\mathrm{Y}$ signifikan antara variabel insentif $(\mathrm{X})$ terhadap variabel kinerja guru $(\mathrm{Y})$.

\section{KESIMPULAN DAN SARAN Kesimpulan}

Penelitian ini dilakukan guru SMK Mulia Buana Bogor, yang menguji mengenai pengaruh insentif terhadap kinerja guru. Berdasarkan hasil analisis dari pembahasan maka dapat diambil kesimpulan sebagai berikut :

1. Pelaksanaan Pemberian insentif dinyatakan sudah cukup baik dapat dilihat dari respon guru atas insentif yang diberikan SMK Mulia Buana Bogor menyatakan sangat setuju $31,09 \%$ ditambah yang menjawab setuju $38,94 \%$ dengan jumlah 70,03\%.

2. Kinerja guru pada SMK Mulia Buana Bogor dijalankan dengan cukup baik oleh para guru terlihat respon guru atas kinerja guru SMK Mulia Buana Bogor menyatakan sangat setuju $34,58 \%$, setuju $36,10 \%$ dengan jumlah $70,68 \%$

3. Pengaruh insentif terhadap kinerja guru SMK Mulia Buana Bogor sebesar 0,546 yang berarti mempunyai kekuatan pengaruh yang cukup kuat. Koefisien determinasi senilai $29,81 \%$ Hal ini menunjukan bahwa terdapat pengaruh antara kebijakan insentif terhadap kinerja guru, sehingga $29,81 \%$ dipengaruhi oleh pemberian insentif sedangkan 70,19\% dipengaruhi oleh variabel atau faktor lain.kemudian dari uji signifikansi t hitung didapatkan hasil sebesar 4,6 dimana hasil ini lebih besar dari $\mathrm{t}$ tabel yaitu 1,67 yang artinya terdapat pengaruh yang signifikan antara insentif terhadap kinerja guru.

\section{Saran}

Berdasarkan hasil analisis dan kesimpulan penelitian, maka ada beberapa saran sebagai berikut:

1. Pimpinan sekolah harus lebih memperhatikan kebutuhan guru seperti masalahmasalah jenis pemberian insentif dan kompensasi lainnya yang diberikan kepada para guru, karena dengan pemberian insentif yang baik adil dan layak akan mam- 
pu memotivasi para guru bekerja lebih baik lagi evaluasi jabatan dan pembentukan struktur organisasi disekolah harus benar benar dirasa baik dan adil dirasakan semua guru di SMK Mulia Buana Bogor agar para guru merasa apa yang telah dikerjakan mendapat penghargaan dan pengakuan oleh lembaga.

2. Pimpinan sekolah harus lebih fokus memberikan jenis jenis motivasi kepada para guru agar semangat kerja guru meningkat dan mampu memberikan pelayanan terbaiknya kepada peserta didik dan orangtua peserta didik dengan memotivasi semangat kerja yang tinggi akan menghasilkan kinerja yang baik dan akan berdampak kepada kepuasan bagi para stackholder dilembaga

\section{DAFTAR PUSTAKA}

Bangun, wilson,2012. Manajemen Sumber Daya Manusia. Penerbit: Erlangga, Bandung.

Dessler, Garry. 2006. Manajemen Sumberdaya Manusia, edisi kesepuluh. Penerbit: PT. Indeks. Jakarta.

2012. Manajemen Sumber daya Manusia. Cetakan ke enam belas. Penerbit: PT Bumi Aksara.Jakarta.

Handoko, Hani T. 2008. Manajemen, edisi kedua. Penerbit: BPFE, Yogyakarta,

Hasibuan, Malayu. 2011. Manajemen Sumberdaya Manusia. Penerbit: PT Bumi Aksara, Jakarta.

Mangkunegara, Prabu. 2012. Evaluasi Kinerja SDM. Penerbit : Replika Aditama, Bandung.

Manullang, Marihot. 2004. Manajemen Sumber Daya Manusia. Penerbit: P.T Bumi Aksara, Jakarta.

2013.Metode Penelitian Kombinasi (mixed methods) Penerbit: CV Alfa Beta, Bandung.

Nawawi, Hadari, 2008. Perencanaan SDM untuk Organisasi yang Kompetitif. Penerbit: Gadjah Mada University Press, Yogyakarta.
Notoadmojo, Soekidjo. 2008. Pengembangan Sumberdaya Manusia. Penerbit: Rineka Cipta, Jakarta.

Oktima, Nurul. 2012. Kamus Ekonomi. Penerbit: Aksarra Sinergi Media, Surakarta.

Pangabean, Mutiara. 2005. Manajemen Kinerja. Penerbit: PT Ragrafindo Persada, Jakarta.

2004.Personal Management, terjemahan oleh Agus Darma, Penerbit: Erlangga, Jakarta.

Riva’i, Veitzhal.2009, Manajemen Sumberdaya Manusia untuk Perusahaan. Penerbit: PT Ragrafindo Persada, Jakarta.

Sagala, Syaiful, 2013. Manajemen Strategi dalam Peningkatan Mutu Pendidikan, Penerbit: Alfabeta, Bandung

Sarwoto. 2010. Dasar dasar Organisasi dan Manajemen, Cetakan ke enam belas, Penerbit: Ghalia Indonesia, Jakarta.

Siagian, Dergibson. 2006. Metode Statistika. Penerbit: PT Gramedia Pustaka Utama, Jakarta.

Siagian, Sondang P. 2006. Manajemen Sumberdaya Manusia. Penerbit: Salemba empat, Jakarta.

Simamora, Hendri.2007 Pengembangan Manajemen Sumber Daya Manusia. Penerbit : YKPN, Yogyakarta..

Sinungan, Muchdarsyah. 2007.Produktivitas apa dan bagaimana. Penerbit: Bumi Aksara, Jakarta..

Sugiyono, 2011. Metode Penelitian Kuantitatif Kualitatif ReD. Penerbit: CV Alfa Beta, Bandung.

Sumanjuntak, Reksu J. 2008. Pengantar ekonomi SDM. Penerbit: FEUI. Jakarta.

Supardi, 2014. Kinerja Guru. Penerbit: Raja Grafindo Persada. Jakarta.

Suparmoko. 2007 Metode Penelitian Praktis. Penerbit: BPFE: Yogyakarta.

Suranta, 2010. Manajemen Sumber Daya Manusia. Penerbit: CV Alfa Beta. Bandung.

Sutrisno. 2011. Manajemen Sumber Daya Manusia. Cetakan ke tiga, Penerbit: Kencana Prenada Media Group, Jakarta. 
Suwatno dan doni. 2011. Manajemen SDM dalam Organisasi Publik dan bisnis. Penerbit: CV Alfa Beta, Bandung.

Suwatno dan Yunarsih, 2008 Manajemen Sumber Daya Manusia. Penerbit: CV Alfa Beta. Bandung.

Tabrani, Rusyan, 2000. Kemampuan dasar guru dalam proses belajar mengajar, Penerbit: Remaja Rosdakarya. Bandung.

Zakiyudin, Ais. 2011. Sistem Informasi Manajemen. Penerbit: PT. Mitra Wacana Media. Jakarta. 